\title{
Kinetic Study of Encapsulated $\beta$-Carotene Degradation in Dried Systems: A Review
}

\author{
Vera Lavelli ${ }^{1, *(1)}$ and Jolanta Sereikaite ${ }^{2}$ (1) \\ 1 Department of Food, Environmental and Nutritional Sciences (DeFENS), University of Milan, 20133 Milan, Italy \\ 2 Department of Chemistry and Bioengineering, Vilnius Gediminas Technical University, 10223 Vilnius, Lithuania; \\ jolanta.sereikaite@vgtu.lt \\ * Correspondence: vera.lavelli@unimi.it; Tel.: +39-02-50319172
}

check for updates

Citation: Lavelli, V.; Sereikaitè, J. Kinetic Study of Encapsulated $\beta$-Carotene Degradation in Dried Systems: A Review. Foods 2022, 11, 437. https://doi.org/10.3390/ foods 11030437

Academic Editor: Adil Gani and Danyang Ying

Received: 31 December 2021

Accepted: 30 January 2022

Published: 2 February 2022

Publisher's Note: MDPI stays neutral with regard to jurisdictional claims in published maps and institutional affiliations.

Copyright: (C) 2022 by the authors. Licensee MDPI, Basel, Switzerland. This article is an open access article distributed under the terms and conditions of the Creative Commons Attribution (CC BY) license (https:// creativecommons.org/licenses/by/ $4.0 /)$.

\begin{abstract}
Carotene serves as a precursor of vitamin A and provides relevant health benefits. To overcome the low bioavailability of $\beta$-carotene from natural sources, technologies have been designed for its encapsulation in micro- and nano-structures followed by freeze-drying, spray-drying, supercritical fluid-enhanced dispersion and electrospraying. A technological challenge is also to increase $\beta$-carotene stability, since due to its multiple conjugated double bonds, it is particularly prone to oxidation. This review analyzes the stability of $\beta$-carotene encapsulated in different dried microand nano-structures by comparing rate constants and activation energies of degradation. The complex effect of water activity and glass transition temperature on degradation kinetics is also addressed, since the oxidation process is remarkably dependent on the glassy or collapsed state of the matrix. The approaches to improve $\beta$-carotene stability, such as the development of inclusion complexes, the improvement of the performance of the interface between air and oil phase in which $\beta$-carotene was dissolved by application of biopolymer combinations or functionalization of natural biopolymers, the addition of hydrophilic small molecular weight molecules that reduce air entrapped in the powder and the co-encapsulation of antioxidants of various polarities are discussed and compared, in order to provide a rational basis for further development of the encapsulation technologies.
\end{abstract}

Keywords: $\beta$-carotene; encapsulation; water activity; glass transition; kinetics; drying

\section{Introduction}

Vitamin A deficiency is a serious health problem especially in low and middle-income countries and affects approximately $33 \%$ of preschool-age children around the world. It is essential for vision, especially dark adaptation, bone growth and reproduction and it maintains integrity of various tissues [1]. Among others, vitamin A plays an essential role in immune system function and is called "the anti-infective vitamin". Vitamin A deficiency weakens the host response to infection. Those functions of vitamin A are of primary importance in the context of the new infection COVID-19 [2,3].

$\beta$-Carotene serves as a precursor of vitamin $A$. In humans, dietary $\beta$-carotene is cleaved to two molecules of all-trans retinal by the action of $\beta, \beta$-carotene $15,15^{\prime}$-monooxygenase 1 . Subsequently, retinal can be reduced into retinol by a retinal reductase or oxidized into retinoic acid by the action of retinal dehydrogenase [4]. $\beta$-Carotene is one of the most potent antioxidants. It not only quenches singlet oxygen but also inhibits lipid peroxidation [5] $\beta$-Carotene reduces the risk of Alzheimer's disease [6], has a protective effect against cardiovascular diseases [7] and type 2 diabetes [8] and decreases the incidence of blindness [9]. It is also believed to prevent cancer [10]. $\beta$-Carotene is found in various fruits and vegetables, while vitamin A is present in food of animal origin [11]. Hence, $\beta$-carotene could play a significant role as a source of vitamin $\mathrm{A}$ in the perspective of replacing animal-source foods with plant-based foods, in order to address environmental, food security and public health objectives [12]. However, $\beta$-carotene is poorly bioavailable from its native vegetable 
sources $[13,14]$ and it is particularly sensitive to degradation [15-17]. In fact, due to its many conjugated double bonds, $\beta$-carotene is prone to autooxidation during food processing [15-20]. Factors that accelerate $\beta$-carotene degradation are temperature, light, oxygen radicals, free radicals formed by lipid peroxidation and transition metal cations [15]. The pathway for $\beta$-carotene degradation was proposed to begin with a cis-trans isomerization that may take place at C9-10 or C13-14 or C15-15' and is followed by the rupture of the cis double bond, with the generation of a diradical molecule with an oxygen bound to just one carbon atom; then, a peroxide intramolecular cycle is formed that triggers the formation of apocarotenoids upon its rupture $[17,18]$. Some studies demonstrated that $\beta$-carotene isomerization is a reversible process and the cis isomers can be converted into each other or also return to the all-trans form. However, the rate constant of $\beta$-carotene degradation into oxidation and cleavage products is an order of magnitude larger than the rate constants of isomerization, indicating that degradation is favored above isomerization [17]. It is worth noticing that the study of the single reaction steps is the only approach to get insight into the actual reaction pathway. On the other hand, the majority of the kinetic models to describe $\beta$-carotene degradation in food systems are empirical models of the global process, based on $\beta$-carotene decay. Empirical models do not provide insight on the single steps but represent a straightforward and pragmatic approach to study $\beta$-carotene decay during food processing [17]. For $\beta$-carotene degradation, a first-order kinetics was most often found for the global process and the effect of temperature on the rate constant was found to follow the Arrhenius equation [17].

Given the susceptibility of $\beta$-carotene to degradation, technological strategies are searched to improve its stability. A promising approach is extraction of $\beta$-carotene from largely accessible sources, mainly carrot and mango peels [21], thus applying the criteria of circular food processing systems [22]. Then, specific micro- or nano-structures are developed to encapsulate $\beta$-carotene, in order to improve its bioaccessibility and stability [23]. The stability of encapsulated $\beta$-carotene in aqueous environments has been reviewed [24]. Encapsulated $\beta$-carotene is also obtained in dried structures since drying is particularly important in view of food distribution within the global food system [25]. The term "dry chain" was introduced to describe food chains where dehydration is applied to food products to prevent microbial growth [25]. Even if drying is a highly energy consuming operation [26], it provides the advantage that no further infrastructures, equipment and energy input are required to maintain product quality during storage and transport.

This review study illustrates the main technologies to produce $\beta$-carotene encapsulated in dried matrices. Then, it focuses on the kinetic data of $\beta$-carotene degradation (rate constants, activation energy) as affected by the formulation, water activity (aw) and glass transition temperature $(\mathrm{Tg})$ of the matrix. As a comparison, kinetic data on $\beta$-carotene degradation in a natural source of $\beta$-carotene such as dried carrot is also reported. The aim is to derive knowledge to increase $\beta$-carotene stability in the food structures. The choice of selecting a pure carotenoid compound instead of a natural carotenoid-rich extract allowed to understand the behavior of different compounds used for micro- and nano-structure formation.

\section{Methods}

\subsection{Literature Study}

The literature study was performed in the period 2013-2021 using two databases (Scopus and Web of Science). Firstly, the search included the following keywords: "carotene" and "water activity" or "carotene" and "glass transition". Papers reporting the development of an encapsulation technology for $\beta$-carotene and the kinetic study of its stability were selected. Other relevant papers were found among those cited in the papers published from 2013 to 2021. In order to compare the kinetic data obtained by various authors, the stability of the system under dark conditions was only considered since the effect of light exposure was reported only in a few studies, with different lighting conditions applied, thus excluding the opportunity of comparison. 


\subsection{Modelling}

In most of the studies the kinetic for $\beta$-carotene degradation was fitted to a first-order kinetics as following Equation (1) [17],

$$
\mathrm{Ct} / \mathrm{Co}=\exp (-\mathrm{k} \times \mathrm{t})
$$

where $\mathrm{Ct}$ is $\beta$-carotene concentration at time $\mathrm{t}$, Co is the initial concentration of $\beta$-carotene, $\mathrm{t}$ is the storage time, $\mathrm{k}$ is the degradation rate constant at the temperature considered.

A special case of first-order model is the fractional conversion model, which can be applied when a fraction of compound under study remains after the kinetic study and is expressed as following Equation (2) [27]:

$$
\left(\mathrm{Ct}-\mathrm{C}_{\infty}\right) /\left(\mathrm{Co}-\mathrm{C}_{\infty)}=\exp (-\mathrm{k} \times \mathrm{t})\right.
$$

where $\mathrm{Ct}, \mathrm{Co}, \mathrm{k}$ and $\mathrm{t}$ are the same as in Equation (1), $\mathrm{C}_{\infty}$ is the asymptotic value to which the retention approaches at a very long time; if $\mathrm{C}_{\infty} \mapsto 0$ the equation tends to a first-order kinetic model.

Alternatively, the Weibull model was applied as following Equation (3) [27]:

$$
\mathrm{Ct} / \mathrm{Co}=\exp \left[-(\mathrm{k} \times \mathrm{t})^{\mathrm{n}}\right]
$$

where $\mathrm{Ct}, \mathrm{Co}, \mathrm{k}$ and $\mathrm{t}$ are the same as in Equation (1) and $\mathrm{n}$ is a shape factor. The Weibull model is flexible owing to the inclusion of the shape constant in addition to the rate constant. If the degradation rate increases over time then the shape factor is greater than 1 , if the degradation rate decreases over treatment time then the shape factor is less than 1 and if degradation rate is constant over time the shape factor is 1 (i.e., first-order kinetics) [27].

If not indicated by the original paper, the half-life of $\beta$-carotene was interpolated by the graphs in the study reporting the time course of degradation during storage. Alternatively, the half-life $\left(t_{1 / 2}\right)$ was calculated as the following Equation (4):

$$
t_{1 / 2}=(0.693)^{\wedge(1 / n)} / k
$$

where $t_{1 / 2}$ is the half-life; $k$ is the same as in Equations (1)-(3) and $n$ is the shape factor as indicated in Equation (3) or $\mathrm{n}=1$ in Equation (1).

To calculate the activation energy, if not reported in the original paper, the Arrhenius equation was used, as following Equation (5):

$$
\ln \left(\mathrm{k}_{1} / \mathrm{k}_{2}\right)=\left(1 / \mathrm{T}_{2}-1 / \mathrm{T}_{1}\right) \times \mathrm{Ea} / \mathrm{R}
$$

where $k_{1}$ and $k_{2}$ are the rate constants at the temperatures $T_{1}$ and $T_{2}$ (Kelvin), respectively, Ea is the activation energy $(\mathrm{J} / \mathrm{mol}), \mathrm{R}$ is the universal gas constant $\left(8.314 \mathrm{~J} \times \mathrm{K}^{-1} \times \mathrm{mol}^{-1}\right)$ [17].

\section{Results}

\subsection{Technologies for $\beta$-Carotene Encapsulation in Dried Systems}

The preliminary step for $\beta$-carotene encapsulation is the extraction from natural sources. Due to its high hydrophobicity, $\beta$-carotene is extracted using organic solvents such as hexane, acetone, methanol and ethanol, as well as various solvent combinations [11]. Efficient and sustainable approaches have also been developed for $\beta$-carotene extraction, based on the application of pulsed electric fields [28], microwaves [29,30], ultrasounds [31], supercritical fluids $[32,33]$ and pressurized liquids $[34,35]$. $\beta$-carotene was also extracted from carrot peel waste by a green procedure without any solvent, based on water-induced hydrocolloidal complexation with pectin [36]. Then, various of micro- and nano-structures designed for $\beta$-carotene encapsulation, such as inclusion complexes, single-layer and multilayer oil-in-water $(\mathrm{O} / \mathrm{W})$ emulsions, as well as double water-in-oil-in-water $\left(\mathrm{W}_{1} / \mathrm{O} / \mathrm{W}_{2}\right)$ emulsions, are produced in liquid phase and dried [37,38]. 
Freeze-drying is often applied to dehydrate pre-formed micro- and nano-structures that encapsulate $\beta$-carotene. Freeze-drying is characterized by three steps: (a) freezing (b) primary drying that occurs below the triple point $\left(\right.$ at $0.01^{\circ} \mathrm{C}$ and $\left.0.612 \mathrm{kPa}\right)$ when ice is sublimated; and (c) secondary drying, when the remaining unfrozen/bound water is desorbed from the drier food matrix [39]. Parameters which describe the freeze-drying process are freezing temperature and rate, working pressure, shelf temperature $\left(30-50^{\circ} \mathrm{C}\right)$ and processing time [40]. In most studies these parameters are not specified. Freezing temperature and rate are important for the formation and size of ice crystals. Indeed, fast freezing rate produces small ice crystals. The ice crystal size affects heat and mass transfer properties during dehydration as well as porosity and rehydration of the dried product [28]. The sublimation process is strongly affected by pressure, which determines the ice sublimation temperature. To avoid the loss of product structure, during the primary drying the temperature should be below the collapse temperature, which is generally 2 to $20{ }^{\circ} \mathrm{C}$ higher than $\mathrm{Tg}$. The shelf temperature is also important since in the secondary drying the product temperature increases to approach that of the shelves. Whatever the processing conditions, freeze-drying is considered to cause little damage to bioactive compounds and to the product structure [39]. On the other hand, the porous structure of the obtained powders, which is desirable for rehydration, could affect the stability of encapsulated bioactive compounds during storage since the presence of micropores increases the contact area that allows the diffusion of oxygen through the polymer matrix and thus decreases the oxidative stability of freeze-dried products [41]. Moreover, freeze-drying has the drawback to be the most expensive process for manufacturing a dehydrated product, having 4 to 10 times more energy requirements than hot air drying [39].

Spray-drying has also been used as an alternative to freeze-drying to obtain encapsulated $\beta$-carotene in dried matrices. As for other lipophilic bioactive compounds, in a first step micro- or nano-encapsulation of $\beta$-carotene is obtained in the aqueous phase, then spray-drying is applied [42]. Spray drying consists of three steps: atomization of feed sample, drying of liquid droplets and powder recovery [43]. During atomization, liquid feed is passed through an atomizer to the drying chamber and distributed into tiny liquid particles. In fact, the atomization maximizes the surface volume area of liquid feed for efficient drying. The properties of the final product depend on the formulation and combination of different processing conditions, which include feed concentration, inlet temperature $\left(110-220^{\circ} \mathrm{C}\right)$, feed flow rate $(2-600 \mathrm{~mL} / \mathrm{h})$, drying air flow rate, type of atomizer and atomizer speed [43]. These conditions affect retention of bioactive compounds and also the size and shape of the powder. In general, small particles are desirable because larger particles might be hollow inside and have a less compact structure, which leads to relatively low bulk density compared to fine particle. Spray drying generally produces powders with higher bulk density than freeze-drying, i.e., with little micropores, which is positive because it reduces packaging and shipping costs and increases flowability [44]. Spray-drying is more economic than freeze-drying but it can cause loss of $\beta$-carotene during processing due to the high temperatures applied and large contact surface with air. Despite the fact that spray-drying has been widely used for carotenoid encapsulation, different results have been described and optimal processing conditions are still to be identified.

Supercritical fluid technology has also been employed to encapsulate $\beta$-carotenerich oils through solution-enhanced dispersion (SEDS). In general, the components to be encapsulated by SEDS are initially dissolved in a suitable organic solvent by vigorous mixing, and then they are rapidly sprayed along with the supercritical fluid through a coaxial nozzle into a high-pressure vessel, which generates small-sized droplets. Then, the mass transfer of the solvent to the supercritical fluid at a high rate results in the formation of small-sized particles. Factors that affect processing efficiency are temperature, pressure, supercritical fluid used as well as organic solvents (if used) and their flow rates, as well as the component nature and concentrations [45]. Among all the supercritical fluids available, supercritical $\mathrm{CO}_{2}\left(\mathrm{SC}-\mathrm{CO}_{2}\right)$ has attracted enormous interest due to its wide adaptability, safety, cost-effectiveness, and requiring mild conditions for operation (temperature $31.1^{\circ} \mathrm{C}$ 
and pressure 73.8 bar) [46]. The challenge in this technique is to replace the use of organic solvent with water. In fact, water has a low solubility in $\mathrm{SC}-\mathrm{CO}_{2}$ [33] in comparison with organic solvents commonly used for SEDS. Hence, the use of $\mathrm{O} / \mathrm{W}$ emulsions in the place of solvent requires a process setup in order to improve water solubility in $\mathrm{SC}-\mathrm{CO}_{2}$. For instance, the water removal efficiency can be raised by increasing the pressure and temperature [47].

Electrospraying has also been proposed for $\beta$-carotene encapsulation. Electrospraying is an electrohydrodynamic processes, where a polymer solution is sprayed by the application of high potential electric field to obtain particles [48]. The typical setup for electrospraying consists of four main components: (i) a high voltage source (1-30 kV); (ii) a blunt ended stainless steel needle or capillary; (iii) a syringe pump; and (iv) a grounded collector either flat plate or rotating drum. The process is run at ambient temperature [36]. The first step of lipophilic compounds encapsulation consists in the preparation of a $\mathrm{O} / \mathrm{W}$ emulsion. The emulsion is atomized by electrical forces into highly charged droplets that are self-dispersing in space, thereby preventing droplet agglomeration and coagulation. Further, evaporation of the solvent leads to contraction and solidification of droplets resulting in solid polymeric particles deposited on the grounded collector. Parameters that affect the process include electrical potential applied, flow rate of the solution and distance between the tip of the needle and the collector [49].

Overall, drying processes could affect the stability of $\beta$-carotene. In fact, exposure to air and high temperatures could promote chemical degradation, while heating, freezing and shear-stress during processing could cause the rupture of the pre-formed micro- and nanostructures, releasing $\beta$-carotene, which becomes exposed to degradation. Moreover, the drying process affects the number and size of the pores of the powder, which entrap oxygen. Hence, encapsulation efficiency and bulk density are relevant parameters for powder stability and they will be considered in the following analysis of $\beta$-carotene degradation rate, when available.

\subsection{Water Activity and Glass Transition Temperature Effect on Dried Product Stability}

Drying of $\beta$-carotene encapsulated into micro- and nanostructures should reach a final aw level at which matrix stability is maximum. In fact, aw is a thermodynamic parameter that affects the rate of microbiological, chemical and physical phenomena [50]. There is a threshold water activity below which no microorganism can grow, which varies slightly depending on the composition of food matrix. Pathogenic bacteria cannot grow below aw of 0.85 , whereas yeasts and molds are more tolerant to reduced aw, but usually no growth occurs below aw of about 0.6 [51]. Conversely, both chemical and physical modifications can occur in dried foods over a wide aw range with different rates, affecting the stability of bioactive compounds. $\beta$-carotene degradation follows an oxidative pathway that is triggered by lipid oxidation and transition metal cations. Lipid oxidation in dried foods generally displays a U-shaped curve with respect to aw level. In fact, minimum oxidation rate for lipids occurs when sample moisture is near the Guggenheim-Anderson-de Boer (GAB) monolayer value, which typically is when aw is between 0.2 and 0.4 ; above and below this range lipid oxidation rate increases remarkably [52]. The decrease of oxidation rate that occurs with change from the anhydrous state to intermediate moisture values (0.2-0.4) has been attributed to multiple factors: the hydration of transition metal cations, rendering them less active promoters of autoxidation; the movement of lipid hydroperoxides to oil-water boundaries and their exclusion from the propagation reactions due to hydrogen bonding with water; the free radical termination reactions due to the movement of polar radicals at the oil-water interfaces. With increase of aw from intermediate values to above 0.7 , lipid oxidation rate increases again owing to the increased mobility of transition metal cations and the decreased viscosity. Further increase in aw decreases unsaturated lipid degradation because of the dilution of reacting species. It is worth noting that the specific aw range at which oxidation occurs at the lowest rate is difficult to predict as it depends on the matrix composition [52]. 
The Tg is another thermodynamic parameter that affects food stability. Tg is the temperature above which a hard amorphous solid will transform into a soft, rubbery material. The Tg depends on matrix composition as well as on the moisture content. In fact, as water content increases, $\mathrm{Tg}$ decreases; thus, $\mathrm{Tg}$ also decreases with increasing aw [52-54]. Materials in the glassy state have very high viscosity and heating to $\mathrm{T}>\mathrm{Tg}$ results in a marked reduction of viscosity and increase in molecular mobility. In general, in the glassy state various chemical reactions may become diffusion limited and foods are stable as compounds involved in deteriorative reactions take many months or even years to diffuse over molecular distances and approach close enough to each other to react [52-54]. In fact, the rate of some reactions increases as the difference between the storage temperature $(\mathrm{T})$ and $\mathrm{Tg}$ increases [52-54]. However, $\beta$-carotene degradation occurs via an oxidative pathway and oxygen, being a small molecule, can diffuse within glassy solids [53]. Accordingly, oxidative processes have been observed to occur at sub-Tg temperatures [54,55]. Oxygen was found to permeate from atmospheric air into oil encapsulated in a glassy matrix (a food model made from sucrose, maltodextrin and gelatin) [56]. Interestingly, in this latter system, a fraction of oil was found to oxidize rapidly and another fraction of oil was found to oxidize more slowly, due to inhomogeneity in the degree of encapsulation. Hence, the efficiency of encapsulation and the oxygen barrier properties of the encapsulation system are fundamental to prevent $\beta$-carotene oxidation [56]. Moreover, the rate of oxidation is related to the collapse phenomenon [52,57]. In fact, at $\mathrm{T}>\mathrm{Tg}$, the material undergoes structural collapse, which is defined as the readily visible deformation (or shrinkage) of the sample under the force of gravity during storage of a dried amorphous matrix $[52,57]$. The non-collapsed glassy systems are more porous then rubbery systems and thus they allow easier diffusion of oxygen. Conversely, at $\mathrm{T}>\mathrm{Tg}$, collapse of dried materials occurs and it is associated with the disappearance of micropores and cavities, which limits oxygen access to oxygen-sensitive targets [41].

Overall, kinetic data on the degradation of oxygen-sensitive compounds such as $\beta$ carotene in dried matrices are not "generally valid", but they are relative to the specific aw and $\mathrm{Tg}$ of the matrix. Moreover, when dried matrices are in contact with an environment with a given relative humidity, they come to the equilibrium aw through absorption or desorption of water [25]. This change in the aw and consequently in the Tg is likely to affect the rate of oxidative reactions. The description of the efficacy of $\beta$-carotene encapsulation technologies in dried system should therefore include the study of $\beta$-carotene stability over a wide aw and Tg range, in order to address the complexity of the relationships between moisture and stability. Hence, in the following paragraphs the kinetic data for $\beta$-carotene degradation are discussed with specific reference to the aw and $\mathrm{Tg}$ of the matrix. When these thermodynamic data were not available, the efficacy of the matrix system on $\beta$-carotene protection could not be fully demonstrated.

\subsection{Rate of $\beta$-Carotene Degradation in Carrot Powder}

The effect of aw on the stability of total carotenoids ( $\alpha$-carotene, $\beta$-carotene and lutein) in carrot powder was found to resemble the stability map observed for unsaturated lipids [58]. In fact, in dehydrated carrots, stored in the aw range $0.0-0.73$, the rate of total carotenoid degradation as a function of aw showed a U-shaped curve and carotenoids were more stable in the aw range 0.32-0.57 [59]. Accordingly, in a following study the rate of $\beta$-carotene degradation in freeze-dried carrots was found to be at a minimum over the aw range $0.31-0.54$, which was close to the GAB monolayer, with a half-life of $11-14 \mathrm{~d}$ at $40{ }^{\circ} \mathrm{C}$. Below and above this aw range, $\beta$-carotene stability decreased markedly, with a half-life of 7, 8 and $3 \mathrm{~d}$ at aw 0.10, 0.22 and 0.75, respectively [60] (Table 1). Considering the activation energy values reported previously [21] (Table 2), the half-life was calculated at $25^{\circ} \mathrm{C}$ using the Arrhenius equation and found to be low, i.e., 9,12 and $16 \mathrm{~d}$ at aw 0.10 , 0.22 and 0.31 , respectively. The possibility to predict carotenoid stability in carrots based on $\mathrm{Tg}$ was investigated. A differential scanning calorimetry study of carrot powder revealed the existence of two $\mathrm{Tg}$. The first $\mathrm{Tg}$ increases from -41.84 to 40.27 with decreasing aw from 
0.75 to 0.11 and depends mainly on the presence of small molecules, such as sugars, organic acids and amino acids. The second Tg increases from 28.65 to $64.69{ }^{\circ} \mathrm{C}$ with decreasing aw from 0.75 to 0.11 and is associated to high molecular weight compounds, namely, starch, fibers and a small amount of proteins [61]. These data explain the low stability of carotenoids in carrot powder at aw 0.75 at $40{ }^{\circ} \mathrm{C}$, because the difference between storage temperature and $\mathrm{Tg}$ is maximum. On the other hand, the low stability of carotenoids at aw 0.11 is not coherent with the high $\mathrm{Tg}$ associated to this aw value. Other factors are likely involved in poor stability, such as the presence of micropores in the glassy structure that favor the contact between air and solids, as observed in model glassy systems entrapping carotenoids [41].

Table 1. Dried systems for the delivery of $\beta$-carotene: matrix ingredient, structure, average particle size (PS, $\mu \mathrm{m})$, water activity (aw), glass transition temperature $\left(\mathrm{Tg},{ }^{\circ} \mathrm{C}\right)$, degradation rate constants $\left(\mathrm{k} \times 10^{3}, \mathrm{~d}^{-1}\right)$ and half-life $\left(\mathrm{t}_{1 / 2}, \mathrm{~d}\right)$ for $\beta$-carotene during storage in the dark at a given temperature $\left({ }^{\circ} \mathrm{C}\right)$.

\begin{tabular}{|c|c|c|c|c|c|c|c|c|}
\hline Matrix Ingredients & Matrix Structure & PS & $\mathrm{T}$ & aw & $\mathrm{Tg}$ & $\mathbf{k} \times 10^{3}$ & $t_{1 / 2}$ & Ref. \\
\hline carrot & FD powder & $\begin{array}{l}\text { n.d. } \\
\text { n.d. } \\
\text { n.d. } \\
\text { n.d. } \\
\text { n.d }\end{array}$ & 40 & $\begin{array}{l}0.10 \\
0.22 \\
0.31 \\
0.53 \\
0.75\end{array}$ & $\begin{array}{c}40.64 \\
13.45 \\
-11.44 \\
-20.38 \\
-41.29\end{array}$ & $\begin{array}{l}104^{\mathrm{a}} \\
82^{\mathrm{a}} \\
62^{\mathrm{a}} \\
48^{\mathrm{a}} \\
271^{\mathrm{a}}\end{array}$ & $\begin{array}{c}7 \\
8 \\
11 \\
14 \\
3\end{array}$ & $\begin{array}{c}\mathrm{k} \\
{[60]} \\
\mathrm{Tg} \\
{[61]}\end{array}$ \\
\hline \multirow{2}{*}{$\begin{array}{l}\beta \text {-carotene, polyvinyl pyrrolidone } \\
\quad-40 \text { and gelatin }\end{array}$} & FD molecular complexes & $\begin{array}{l}\text { n.d. } \\
\text { n.d } \\
\text { n.d. }\end{array}$ & \multirow[t]{2}{*}{25} & $\begin{array}{l}0.11 \\
0.44 \\
0.53\end{array}$ & $\begin{array}{l}86 \\
50 \\
25\end{array}$ & $\begin{array}{l}270^{b} \\
220^{b} \\
110^{b}\end{array}$ & $\begin{array}{l}2 \\
3 \\
6\end{array}$ & \multirow[t]{2}{*}{ [62] } \\
\hline & $\begin{array}{c}\text { collapsed } \\
\text { molecular complexes }\end{array}$ & $\begin{array}{l}\text { n.d. } \\
\text { n.d }\end{array}$ & & $\begin{array}{l}0.64 \\
0.75\end{array}$ & $\begin{array}{c}7 \\
-9\end{array}$ & $\begin{array}{l}10^{b} \\
7^{b}\end{array}$ & $\begin{array}{l}69 \\
99\end{array}$ & \\
\hline$\beta$-carotene, $\beta$-cyclodextrins/epiclon & FD molecular complexes & 0.65 & \multirow[b]{2}{*}{25} & n.d. & n.d. & n.d. & 5 & \multirow[b]{2}{*}{ [63] } \\
\hline $\begin{array}{l}\beta \text {-carotene, } \beta \text {-cyclodextrins / } \\
\text { hexamethylene diisocyanate }\end{array}$ & FD molecular complexes & 0.59 & & n.d. & n.d. & n.d. & 5 & \\
\hline $\begin{array}{l}\beta \text {-carotene, amylose, } \\
\text { ascorbyl palmitate }\end{array}$ & RT molecular complexes & n.d. & 20 & n.d. & n.d. & $32.8^{a}$ & 26 & [64] \\
\hline \multirow{2}{*}{$\begin{array}{l}\beta \text {-carotene, sunflower oil, } \\
\text { maltodextrins DE } 4\end{array}$} & FD O/W emulsion & $\begin{array}{l}\sim 2 \\
\sim 2\end{array}$ & \multirow{6}{*}{24} & $\begin{array}{l}0.00 \\
0.35\end{array}$ & $\begin{array}{l}\text { n.d. } \\
\text { n.d. }\end{array}$ & $\begin{array}{l}\sim 16^{\mathrm{a}} \\
\sim 14^{\mathrm{a}}\end{array}$ & $\begin{array}{l}\sim 43 \\
\sim 50\end{array}$ & \multirow{6}{*}{ [65] } \\
\hline & collapsed $\mathrm{O} / \mathrm{W}$ emulsion & $\sim 2.5$ & & 0.75 & n.d. & $\sim 12^{\mathrm{a}}$ & $\sim 58$ & \\
\hline \multirow{2}{*}{$\begin{array}{l}\beta \text {-carotene, sunflower oil, } \\
\text { maltodextrins DE } 10\end{array}$} & FD O/W emulsion & $\begin{array}{l}\sim 3 \\
\sim 3\end{array}$ & & $\begin{array}{l}0.00 \\
0.35\end{array}$ & $\begin{array}{l}\text { n.d. } \\
\text { n.d. }\end{array}$ & $\begin{array}{l}\sim 18^{\mathrm{a}} \\
\sim 18^{\mathrm{a}}\end{array}$ & $\begin{array}{l}\sim 39 \\
\sim 39\end{array}$ & \\
\hline & collapsed $\mathrm{O} / \mathrm{W}$ emulsion & $\sim 4$ & & 0.75 & n.d. & $\sim 10^{\mathrm{a}}$ & $\sim 69$ & \\
\hline \multirow{2}{*}{$\begin{array}{l}\beta \text {-carotene, sunflower oil, } \\
\text { maltodextrins DE } 25.5\end{array}$} & FD O/W emulsion & $\begin{array}{l}\sim 4 \\
\sim 4\end{array}$ & & $\begin{array}{l}0.00 \\
0.35\end{array}$ & $\begin{array}{l}\text { n.d. } \\
\text { n.d. }\end{array}$ & $\begin{array}{l}\sim 14^{\mathrm{a}} \\
\sim 10^{\mathrm{a}}\end{array}$ & $\begin{array}{l}\sim 50 \\
\sim 69\end{array}$ & \\
\hline & collapsed $\mathrm{O} / \mathrm{W}$ emulsion & $\sim 7$ & & 0.75 & -28 & $\sim 7^{\mathrm{a}}$ & $\sim 99$ & \\
\hline$\beta$-carotene, sunflower oil, & FD O/W emulsion & $\begin{array}{l}5.1 \\
\text { n.d. }\end{array}$ & \multirow{4}{*}{25} & $\begin{array}{l}0.10 \\
0.45\end{array}$ & $\begin{array}{l}\text { n.d. } \\
\text { n.d. }\end{array}$ & $\begin{array}{c}24^{\mathrm{a}} \\
39.7^{\mathrm{a}}\end{array}$ & $\begin{array}{l}28 \\
17\end{array}$ & \multirow{4}{*}{ [66] } \\
\hline $\mathrm{Al}$ & collapsed $\mathrm{O} / \mathrm{W}$ emulsion & n.d. & & 0.80 & n.d. & n.d. & $>70$ & \\
\hline \multirow{2}{*}{$\begin{array}{l}\beta \text {-carotene, sunflower oil, } \\
\text { Almond gum }\end{array}$} & FD O/W emulsion & $\begin{array}{l}3.7 \\
\text { n.d. }\end{array}$ & & $\begin{array}{l}0.10 \\
0.45\end{array}$ & $\begin{array}{l}\text { n.d. } \\
\text { n.d. }\end{array}$ & $\begin{array}{c}17.8^{\mathrm{a}} \\
25^{\mathrm{a}}\end{array}$ & $\begin{array}{l}40 \\
28\end{array}$ & \\
\hline & collapsed $\mathrm{O} / \mathrm{W}$ emulsion & n.d. & & 0.80 & n.d. & n.d. & $>70$ & \\
\hline
\end{tabular}


Table 1. Cont.

\begin{tabular}{|c|c|c|c|c|c|c|c|c|}
\hline Matrix Ingredients & Matrix Structure & PS & $\mathbf{T}$ & aw & $\mathrm{Tg}$ & $\mathbf{k} \times 10^{3}$ & $\mathbf{t}_{1 / 2}$ & Ref. \\
\hline \multirow{2}{*}{$\begin{array}{c}\beta \text {-carotene, sunflower oil, } \\
\text { Arabic gum }\end{array}$} & SD O/W emulsion & 3.2 & \multirow{4}{*}{25} & $\begin{array}{l}0.10 \\
0.45\end{array}$ & $\begin{array}{l}\text { n.d. } \\
\text { n.d. }\end{array}$ & $\begin{array}{l}9.6^{\mathrm{a}} \\
30^{\mathrm{a}}\end{array}$ & $\begin{array}{l}72 \\
23\end{array}$ & \multirow{4}{*}[67]{} \\
\hline & collapsed $\mathrm{O} / \mathrm{W}$ emulsion & n.d. & & 0.80 & n.d. & n.d. & n.d. & \\
\hline \multirow{2}{*}{$\begin{array}{l}\beta \text {-carotene, sunflower oil, } \\
\text { Almond gum }\end{array}$} & $\mathrm{SD} \mathrm{O} / \mathrm{W}$ emulsion & 2.1 & & $\begin{array}{l}0.10 \\
0.45\end{array}$ & n.d. & $\begin{array}{l}25^{\mathrm{a}} \\
45^{\mathrm{a}}\end{array}$ & $\begin{array}{l}28 \\
15\end{array}$ & \\
\hline & collapsed $\mathrm{O} / \mathrm{W}$ emulsion & n.d. & & 0.80 & n.d. & n.d. & n.d. & \\
\hline \multirow{3}{*}{$\begin{array}{c}\beta \text {-carotene, sunflower } \\
\text { canola-cartamum oils, gellan } \\
\text { gum, Arabic gum, maltodextrins } \\
\text { DE 10, mono- and di-glycerides, } \\
\text { diacetyl tartaric acid and } \\
\text { polyglycerol polyricinoleate }\end{array}$} & $\mathrm{SD} \mathrm{W}_{1} / \mathrm{O} / \mathrm{W}_{2}$ emulsion & 34 & \multirow[b]{3}{*}{35} & $0.02-0.51$ & n.d. & $23.5^{\mathrm{a}}$ & 21 & \multirow[b]{3}{*}{ [68] } \\
\hline & dissolved emulsion & n.d. & & 0.63 & n.d. & $160^{a}$ & 4 & \\
\hline & gel-like structure & n.d. & & $0.74-0.82$ & n.d. & $20^{\mathrm{a}}$ & 35 & \\
\hline $\begin{array}{l}\beta \text {-carotene, sunflower oil, } \\
\text { trehalose, whey protein }\end{array}$ & FD O/W emulsion & n.d. & \multirow[b]{2}{*}{37} & 0.33 & n.d. & $\sim 23^{\mathrm{a}}$ & $\sim 30$ & \multirow[b]{2}{*}{ [69] } \\
\hline $\begin{array}{c}\beta \text {-carotene, sunflower oil, } \\
\text { trehalose, whey protein, } \\
\text { Arabic gum }\end{array}$ & FD LBL O/W emulsion & n.d. & & 0.33 & n.d. & $\sim 14^{\mathrm{a}}$ & $\sim 49$ & \\
\hline $\begin{array}{l}\beta \text {-carotene, sunflower oil, } \\
\text { trehalose, whey protein }\end{array}$ & FD O/W emulsion & n.d. & \multirow{4}{*}{35} & 0.14 & 50 & n.d. & $>78$ & \multirow{4}{*}{ [70] } \\
\hline $\begin{array}{c}\beta \text {-carotene, sunflower oil, } \\
\text { trehalose, whey protein, } \\
\text { Arabic gum }\end{array}$ & FD LBL O/W emulsion & n.d. & & 0.14 & 50 & n.d. & $>78$ & \\
\hline $\begin{array}{l}\beta \text {-carotene, sunflower oil, } \\
\text { trehalose, maltodextrin DE 23-27, } \\
\text { whey protein }\end{array}$ & $\mathrm{SD} \mathrm{O} / \mathrm{W}$ emulsion & n.d. & & 0.16 & 64 & n.d. & $>99$ & \\
\hline $\begin{array}{c}\beta \text {-carotene, sunflower oil, } \\
\text { trehalose, maltodextrin DE 23-27, } \\
\text { whey protein, Arabic gum }\end{array}$ & SD LBL O/W emulsion & n.d. & & 0.17 & 64 & n.d. & $>99$ & \\
\hline \multirow{2}{*}{$\begin{array}{l}\beta \text {-carotene, palm oil, tocopherols } \\
\text { and tocotrienols, maltodextrins DE } 10, \\
\text { sodium caseinate and soy lecithin }\end{array}$} & SEDS O/W emulsion & 5.8 & \multirow{2}{*}{25} & 0.47 & n.d. & $4.65^{\mathrm{a}}$ & 149 & \multirow{2}{*}{ [71] } \\
\hline & SD O/W emulsion & 16.6 & & 0.40 & n.d. & $3.48^{\mathrm{a}}$ & 199 & \\
\hline$\beta$-carotene, medium chain & & 0.54 & \multirow{18}{*}{25} & 0.2 & n.d & n.d. & 86 & \\
\hline triglycerides, pullulan, & ED O/W emulsion & n.d. & & 0.4 & n.d. & n.d. & 81 & [72] \\
\hline whey protein & & n.d. & & 0.6 & n.d. & n.d. & 46 & \\
\hline \multirow{5}{*}{$\begin{array}{l}\beta \text {-carotene, medium chain } \\
\text { triglycerides, OSA modified } \\
\text { starch HI-CAP }\end{array}$} & & 0.15 & & 0.11 & n.d. & $13(1.2)^{c}$ & 50 & \multirow{15}{*}{ [73] } \\
\hline & SDO/W emulsion & n.d. & & 0.33 & 31 & $14(1.2)^{\mathrm{c}}$ & 46 & \\
\hline & SD U/ W emulsion & n.d. & & 0.52 & 9 & $34(1.5)^{c}$ & 17 & \\
\hline & & n.d. & & 0.75 & -26 & $25(1.4)^{c}$ & 24 & \\
\hline & collapsed emulsion & n.d. & & 0.97 & n.d. & $18(1.0)^{c}$ & 39 & \\
\hline \multirow{5}{*}{$\begin{array}{l}\beta \text {-carotene, medium chain } \\
\text { triglycerides, OSA modified } \\
\text { starch CAPSUL }\end{array}$} & & 0.10 & & 0.11 & n.d. & $34(1.2)^{c}$ & 19 & \\
\hline & SD O/W emulsion & n.d. & & 0.33 & 80 & $39(1.2)^{c}$ & 17 & \\
\hline & SD U/ W emulsion & n.d. & & 0.52 & 73 & $41(1.2)^{c}$ & 16 & \\
\hline & & n.d. & & 0.75 & 55 & $44(1.2)^{\mathrm{c}}$ & 15 & \\
\hline & collapsed $\mathrm{O} / \mathrm{W}$ emulsion & n.d. & & 0.97 & n.d. & $21(0.8)^{c}$ & 36 & \\
\hline \multirow{5}{*}{$\begin{array}{l}\beta \text {-carotene, medium chain } \\
\text { triglycerides, OSA modified } \\
\text { starch CAPSUL TA }\end{array}$} & \multirow{4}{*}{$\mathrm{SD} \mathrm{O} / \mathrm{W}$ emulsion } & 0.11 & & 0.11 & n.d. & $33(1.2)^{c}$ & 20 & \\
\hline & & n.d. & & 0.33 & 83 & $35(1.3)^{c}$ & 18 & \\
\hline & & n.d. & & 0.52 & 75 & $38(1.3)^{c}$ & 16 & \\
\hline & & n.d. & & 0.75 & 56 & $41(1.3)^{c}$ & 15 & \\
\hline & collapsed O/W emulsion & n.d. & & 0.97 & n.d. & $19(1.0)^{c}$ & 36 & \\
\hline
\end{tabular}


Table 1. Cont.

\begin{tabular}{|c|c|c|c|c|c|c|c|c|}
\hline Matrix Ingredients & Matrix Structure & PS & $\mathbf{T}$ & aw & $\mathrm{Tg}$ & $\mathrm{k} \times 10^{3}$ & $t_{1 / 2}$ & Ref. \\
\hline $\begin{array}{l}\beta \text {-carotene, flaxseed oil, eugenol, } \\
\left.\text { OSA starch (MW } 9.4 \times 10^{5}\right)\end{array}$ & $\mathrm{SD} \mathrm{O} / \mathrm{W}$ emulsion & 0.13 & \multirow{2}{*}{40} & 0.28 & n.d. & n.d. & $>30$ & \multirow{2}{*}{ [74] } \\
\hline $\begin{array}{l}\beta \text {-carotene, flaxseed oil, eugenol, } \\
\left.\text { OSA starch (MW } 5.3 \times 10^{6}\right)\end{array}$ & $\mathrm{SD} \mathrm{O} / \mathrm{W}$ emulsion & 0.24 & & 0.19 & n.d. & n.d. & 21 & \\
\hline $\begin{array}{l}\beta \text {-carotene, } \alpha \text {-tocopherol, corn oil, } \\
\text { OSA starch, ascorbic acid, sucrose }\end{array}$ & $\mathrm{SD} \mathrm{O} / \mathrm{W}$ emulsion & 0.25 & 60 & 0.26 & 83 & n.d. & $>30$ & [75] \\
\hline
\end{tabular}

Rate constant and half-life refer all-trans- $\beta$-carotene degradation. ${ }^{a}$ First-order kinetic model. ${ }^{\mathrm{b}}$ Fractional conversion model. ' Weibull model, with the shape value $\mathrm{n}$ indicated in brackets. DE, dextrose equivalents; OSA, N-octenyl succinate anhydride; O, oil; W, water; LBL, layer-by-layer; FD, freeze-dried; RT, roomtemperature dried; $\mathrm{SD}$, spray-dried; SEDS, supercritical $\mathrm{CO}_{2}$. enhanced dispersion dried; ED, electro-sprayed; n.d., not determined.

Table 2. Activation energy $(\mathrm{Ea}, \mathrm{kJ} / \mathrm{mol})$ in the given temperature range $\left(\mathrm{T}\right.$ range, $\left.{ }^{\circ} \mathrm{C}\right)$ and at a specific aw for the degradation of $\beta$-carotene encapsulated in dried micro- and nano-structures.

\begin{tabular}{|c|c|c|c|c|c|}
\hline Matrix Ingredients & Matrix Structure & T Range & aw & Ea & Ref. \\
\hline \multirow{3}{*}{ carrot } & \multirow{3}{*}{ AD powder } & \multirow{3}{*}{$60-80$} & 0.10 & 15.69 & \multirow{3}{*}{ [21] } \\
\hline & & & 0.20 & 16.27 & \\
\hline & & & 0.30 & 17.61 & \\
\hline$\beta$-carotene, amylose, ascorbyl palmitate & RT molecular complexes & $20-30$ & n.d. & 23 (calculated) & [64] \\
\hline $\begin{array}{l}\text { palm oil containing tocopherols and } \\
\text { tocotrienols, maltodextrin DE } 10, \\
\text { sodium caseinate and soy lecithin }\end{array}$ & $\mathrm{SD} \mathrm{O} / \mathrm{W}$ emulsion & $25-85$ & 0.40 & 29 & \multirow{2}{*}{ [71] } \\
\hline $\begin{array}{l}\text { palm oil containing tocopherols and } \\
\text { tocotrienols, maltodexrtin DE } 10, \\
\text { sodium caseinate and soy lecithin }\end{array}$ & SEDS O/W emulsion & $25-85$ & 0.47 & 25 & \\
\hline \multirow{2}{*}{$\begin{array}{l}\beta \text {-carotene, sunflower oil, } \\
\text { trehalose, whey protein }\end{array}$} & \multirow{2}{*}{ FD O/W emulsion } & $25-45$ & 0.14 & 58.29 (below $\mathrm{Tg}$ ) & \multirow{8}{*}{ [70] } \\
\hline & & $45-65$ & 0.14 & 16.81 (above $\mathrm{Tg}$ ) & \\
\hline \multirow{2}{*}{$\begin{array}{l}\beta \text {-carotene, sunflower oil, trehalose, } \\
\text { whey protein, Arabic gum }\end{array}$} & \multirow{2}{*}{ FD LBL O/W emulsion } & $25-45$ & 0.14 & 29.72 (below $\mathrm{Tg}$ ) & \\
\hline & & $45-65$ & 0.14 & 69.83 (above Tg) & \\
\hline \multirow{2}{*}{$\begin{array}{l}\beta \text {-carotene, sunflower oil, trehalose, } \\
\text { maltodextrin DE } 23-27, \text { whey protein }\end{array}$} & \multirow{2}{*}{$\mathrm{SD} \mathrm{O} / \mathrm{W}$ emulsion } & $25-45$ & 0.16 & 23.59 (below Tg) & \\
\hline & & $45-65$ & 0.16 & 16.88 (above $\mathrm{Tg}$ ) & \\
\hline \multirow{2}{*}{$\begin{array}{c}\beta \text {-carotene, sunflower oil, } \\
\text { trehalose, maltodextrin DE 23-27, } \\
\text { whey protein, Arabic gum }\end{array}$} & \multirow{2}{*}{ SD LBL O/W emulsion } & $25-45$ & 0.17 & 12.71 (above $\mathrm{Tg}$ ) & \\
\hline & & $45-65$ & 0.17 & 28.34 (below Tg) & \\
\hline
\end{tabular}

Activation energy refers to refer all-trans- $\beta$-carotene degradation: $\mathrm{DE}$, dextrose equivalents; $\mathrm{O}$, oil; $\mathrm{W}$, water LBL, layer-by-layer; FD, freeze-dried; RT, room temperature dried; AD, air-dried; SD, spray-dried; SEDS, supercritical $\mathrm{CO}_{2}$ enhanced dispersion dried; n.d., not determined.

\subsection{Rate of Encapsulated $\beta$-Carotene Degradation in Dried Systems}

A model polymeric matrix was designed to study the relationship between $\beta$-carotene stability, aw and Tg. In fact, $\beta$-carotene was suspended in aqueous solution of polyvinyl pyrrolidone (PVP-40) and gelatin (encapsulation efficiency was not provided), frozen in liquid nitrogen and then freeze-dried at $-110^{\circ} \mathrm{C}$ and $4 \times 10^{-4} \mathrm{mbar}$. The powder obtained was equilibrated at different aw in the aw range $0.11-0.75$ to investigate storage stability at $25^{\circ} \mathrm{C}$, but the microstructure of the powder and particle size were not specified [62]. The samples at aw $0.11-0.53$ were in the glassy state, while those stored at aw 0.64 and 0.75 were in the supercooled state and showed structural collapse with a rather sticky or compacted macroscopic appearance. The degradation rate constants for $\beta$-carotene were maximum in the glassy state (below $\mathrm{Tg}$ ), where $\beta$-carotene was effectively encapsulated, but the high porosity matrix allowed oxygen diffusion and then a fast degradation, with a half-life lower than $6 \mathrm{~d}$ at $25^{\circ} \mathrm{C}$. Oppositely, the lower degradation rate constants were 
observed at aw 0.64 and 0.75 , with half-lives of about 66 and $99 \mathrm{~d}$, respectively. However, under these conditions the matrix was collapsed; indeed, the matrix was fully plasticized and the structural collapse was supposed to cause the disappearance or the decrease of micropores, through which oxygen could enter or move in the matrix [62].

Other studies have investigated the development of molecular complexes to stabilize $\beta$-carotene. The inclusion agent cyclodextrins were proposed, since cyclodextrins are cyclic oligosaccharides with a hydrophobic cavity for holding hydrophobic guest molecules and a hydrophilic exterior for solubilization. However, theoretical investigations suggested that the incorporation of $\beta$-carotene in $\beta$-cyclodextrins is unstable [76]. Hence, in a following approach, two cross-linkers, epiclon and hexamethylene diisocyanate, were used to stabilize inclusion complex of $\beta$-cyclodextrins with $\beta$-carotene. Water suspensions of $\beta$-carotene and the derivatized cyclodextrins or not-derivatized cyclodextrin were agitated at high speed, followed by freeze drying at $-86^{\circ} \mathrm{C}$ and $4 \times 10^{-2}$ bar [63]. Encapsulation efficiency was $44 \%$ in the absence of crosslinkers and $61 \%$ in the presence of crosslinkers. Porous nanosponges were obtained with average particle size of $654 \mathrm{~nm}$ for the epiclon crosslinker cyclodextrin complex and $590 \mathrm{~nm}$ for the hexamethylene diisocyanate crosslinkers cyclodextrin complex. On the other hand, the aw and Tg of the complexes were not reported. The stability of the inclusion complexes was evaluated at $25{ }^{\circ} \mathrm{C}$ and results showed that both crosslinked and not-crosslinked inclusion complexes provided similar protection to $\beta$-carotene, but the half-life was only approximately $5 \mathrm{~d}$ [63].

Amylose also forms single-helical inclusion complexes with various hydrophobic ligands. As a novel method to encapsulate and stabilize $\beta$-carotene, ternary complexes made of $\beta$-carotene, ascorbyl palmitate and amylose were developed, where ascorbyl palmitate acted as both as emulsifier and an antioxidant food additive. A suspension of water and dimethyl sulfoxide containing $\beta$-carotene, amylose and ascorbyl palmitate was stirred to form the inclusion complexes and then dried at room temperature. $\beta$-carotene showed relatively high stability upon storage at $25^{\circ} \mathrm{C}$, with a half-life of $26 \mathrm{~d}$ [64]. Hence, this approach allowed the better stability of $B$-carotene with respect to the natural matrix carrot [60]. On the other hand, the encapsulation efficiency, the microstructure of the powder, aw and $\mathrm{Tg}$ of the complexes were not reported.

$\mathrm{O} / \mathrm{W}$ emulsions are commonly used for lipophilic bioactive compounds encapsulation [77]. In one study, $\mathrm{O} / \mathrm{W}$ emulsions of $\beta$-carotene in sunflower oil were dispersed in maltodextrin systems with dextrose equivalents (DE) 6, DE 11, and DE 25.5, frozen prior to freeze-drying at $-80{ }^{\circ} \mathrm{C}$ and $<0.1$ mbar for $48 \mathrm{~h}$ (encapsulation efficiency was not provided) [65]. The DE of maltodextrins is inversely related with their $\mathrm{Tg}$ and hence with the viscosity of the solution in which they are dissolved [78]. Therefore, maltodextrin DE 6, DE 11 and DE 25.5 are expected to display different behavior. The freeze-dried emulsions had particle size in the range $2-5 \mu \mathrm{m}$, with the highest value for the emulsion obtained with maltodextrins DE 25.5. The stability of the powders was investigated at aw $0.00,0.33$ and 0.75 , at $24^{\circ} \mathrm{C}$. For all carriers, the highest stability was found at aw 0.75 , i.e., above $\mathrm{Tg}$, where transition of the systems to the rubbery state occurred and increased the size of oil droplets in the range 4-7 $\mu \mathrm{m}$, while the highest value for the emulsion obtained with maltodextrins with DE 25.5 [65]. As a consequence, using maltodextrin DE 25.5 led to a half-life of 50, 69 and $99 \mathrm{~d}$ at aw of $0.00,0.35$ and 0.75 , respectively. Interestingly, this system achieved was much higher $\beta$-carotene stability than that observed in dried carrots. The results also confirmed that structural collapse of the rubbery systems increased $\beta$-carotene stability. Moreover, the increased size of lipid particles as well as thicker encapsulant matrix membranes were found to enhance the stability of dispersed $\beta$-carotene in freeze-dried solids probably die to higher barrier properties toward oxygen diffusion [65].

Compared to the $\mathrm{O} / \mathrm{W}$ emulsions obtained with maltodextrins DE 25.5, the use of Arabic gum or almond gum for $\mathrm{O} / \mathrm{W}$ emulsification of $\beta$-carotene dissolved in sunflower oil followed by freeze-drying turned out to be less effective [66], although it was more effective than the natural matrix, i.e., carrot. The emulsifying properties of Arabic gum depend on $2 \%$ of protein contaminants among its main components that are polysaccharide [79]. Almond 
gum also contains $2.45 \%$ of protein, which contributes to its emulsifying properties [80]. Almond gum exhibited emulsifying properties comparable to Arabic gum, but it displayed slower dynamics of adsorption and reorganization at the oil/water interface [81]. In these systems, $\mathrm{O} / \mathrm{W}$ emulsions of $\beta$-carotene were frozen at $-30{ }^{\circ} \mathrm{C}$ and freeze-dried at $-120{ }^{\circ} \mathrm{C}$ and $0.3 \times 10^{-4}$ mbar for $48 \mathrm{~h}$, with secondary drying at $25{ }^{\circ} \mathrm{C}$ [66]. The encapsulation efficiency ranged between 93.43 and $91.82 \%$ for almond gum and Arabic gum, respectively. The average diameter of the powders was 3.7 and $5.1 \mu \mathrm{m}$ for almond gum and Arabic gum, respectively. The retention of $\beta$-carotene encapsulated with almond gum or Arabic gum was investigated during storage at $25^{\circ} \mathrm{C}$ and the resulting half-life for $\beta$-carotene was 28 and $40 \mathrm{~d}$ at aw 0.1 for Arabic gum and almond gum, respectively. Increasing aw to 0.45 resulted in decreased $\beta$-carotene half-life in both systems, but increased $\beta$-carotene half-life was observed at aw 0.8 when the systems were collapsed.

The use of Arabic gum or almond gum for $\mathrm{O} / \mathrm{W}$ encapsulation of $\beta$-carotene dissolved in sunflower oil, previously obtained by freeze-drying was also applied by spray-drying (diameter nozzle $0.5 \mathrm{~mm}$, pressure of compressed air 2 bar, inlet temperatures were maintained at $180{ }^{\circ} \mathrm{C}$, feed rate was $20 \mathrm{~mL} / \mathrm{min}$ ) [67]. In this system, encapsulation efficiency of 66.4 and $69.8 \%$ were observed for almond gum and Arabic gum, respectively, which are lower than those observed upon freeze drying [66,67]. The average diameter of the powders was 2.1 and $3.2 \mu \mathrm{m}$ for almond gum and Arabic gum, respectively, which are lower than those obtained by freeze-drying. When Arabic gum was applied, during storage at aw 0.1 at $25^{\circ} \mathrm{C}$, the half-life of $\beta$-carotene was $72 \mathrm{~d}$; then it decreased to $23 \mathrm{~d}$ when aw increased from 0.10 to 0.45 . Hence, higher stability was observed for the spray-dried system compared to the freeze-dried system [66,67]. As expected, at aw $0.80 \beta$-carotene stability increased due to the occurrence of glass transition, causing structural collapse and a decrease in the micropores of the matrix. When almond gum was used in the place of Arabic gum, lower stability was found and no difference was observed between the spray-dried and freeze-dried system $[66,67]$.

The development of $\mathrm{W}_{1} / \mathrm{O} / \mathrm{W}_{2}$ emulsions was also proposed for encapsulation of lipophilic compounds [82]. However, for $\beta$-carotene $W_{1} / O / W_{2}$ emulsions did not lead to great improvement of stability. In fact, $\beta$-carotene was dissolved into a commercial blend of sunflower canola-cartamum oils to build the lipid phase, which was emulsified with a solution of gellan gum added with both hydrophilic emulsifiers (esters of monoglycerides and diglycerides of diacetyl tartaric acid) and hydrophobic emulsifiers (esters of polyglycerol polyricinoleate fatty acids). Then, the primary emulsion was re-emulsified in the aqueous solutions of the biopolymers Arabic gum and maltodextrin DE 10 and then spray-dried $\left(20 \mathrm{~mL} / \mathrm{min}, 2.8\right.$ bar air pressure, inlet temperature of $\left.170{ }^{\circ} \mathrm{C}\right)$ [68]. The ratios among various emulsion components were optimized to achieve a microencapsulation efficiency of $87.5 \%$. The particle size was $34 \mu \mathrm{m}$. The emulsions were equilibrated at aw levels in the range $0.022-0.845$, in order to investigate storage stability at $35^{\circ} \mathrm{C}$. $\beta$-carotene degradation kinetics was practically the same in the aw range 0.022 to 0.515 , where it displayed a half-life of $21 \mathrm{~d}$. However, the degradation rate surged to a maximum at aw of 0.628 , which could be due to pro-oxidant effects caused by (a) reduced viscosity promoting mobility, (b) dissolution of precipitated catalysts, and/or (c) swelling of the solid matrices exposing new catalytic surfaces. The glass transition phenomenon was not investigated but stability was correlated to structural modifications. Indeed, in the aw range 0.742 to $0.821, \beta$-carotene degradation rate fell to a minimum constant value, probably due to the formation of a new gel-like compact structure in which $\beta$-carotene was reincorporated in the biopolymer matrix [68].

One strategy to increase $\beta$-carotene stability is to strengthen the interface of the emulsion by applying multilayers of polymers. Moreover, using high concentrations of hydrophilic solids in the emulsion to be dried usually leads to a high bulk density and, hence, a low amount of occluded air in the powder $[69,70]$. A comparison was made between single-layer and layer-by-layer (LBL) emulsions designed to encapsulate $\beta$-carotene and lutein dissolved in sunflower oil. Single-layer emulsions were obtained 
using sunflower oil as the oil phase, whey protein isolate as emulsifiers and trehalose as wall material, while LBL emulsions were obtained by adding Arabic gum as the second layer [69]. In fact, whey proteins at a low $\mathrm{pH}$ can be covered by negatively charged polyelectrolytes, including Arabic gum, to give improved resistance of emulsions against freeze-thaw cycles, lipid oxidation and high salt concentrations. Trehalose was used as a hydrophilic component that can form a continuous solid phase of the dried formulation, though, on the other hand, the bulk density was not measured. The single layer and LBL emulsions were frozen at $-80{ }^{\circ} \mathrm{C}$, freeze-dried at pressure $<0.1 \mathrm{mbar}$ for at least $72 \mathrm{~h}$, but the encapsulation efficiency was not reported. $\beta$-carotene degradation was found to follow two-step first-order kinetics of degradation; the first step was faster and was attributed to the degradation of $\beta$-carotene dissolved in the surface oil, while the second step was attributed to the degradation of encapsulated oil. At $37^{\circ} \mathrm{C}$, the system was not collapsed. Interestingly, the half-life for $\beta$-carotene in both the LBL system and the single-layer system at aw 0.33 and $37^{\circ} \mathrm{C}$ were approximately 30 and $49 \mathrm{~d}$, respectively, which are relatively high and could be attributed to the protecting effect of trehalose [69]. The same freeze-dried $\beta$-carotene encapsulation systems were also studied at aw 0.14 and compared to similar systems obtained by spray-drying (inlet temperature $185^{\circ} \mathrm{C}$ ). For spray-drying, however, maltodextrin DE 23-27 was also included as wall material. Interestingly, the freeze-dried sample showed a relatively high stability at aw 0.14 , as already observed for aw of 0.33 [70], with a half-life higher than $78 \mathrm{~d}$ at $35^{\circ} \mathrm{C}$. The spray-dried samples were even more stable than the freeze-dried samples, with half-lives higher than $99 \mathrm{~d}$. This effect was attributed to less air occluded in the spray-dried emulsions due to the presence of trehalose [70].

Another approach to improve the barrier that protects $\beta$-carotene is to use combination of polysaccharides and proteins. A relevant increase in $\beta$-carotene stability in the glassy state was achieved when $\beta$-carotene and $\alpha$-carotene were emulsified in $O / W$ palm oil emulsion containing tocopherols and tocotrienols, maltodextrin DE 10, sodium caseinate and soy lecithin and then encapsulated by either solution-enhanced dispersion by supercritical carbon dioxide (SEDS) $\left(125\right.$ bar, $50{ }^{\circ} \mathrm{C}, \mathrm{CO}_{2}$ feed $150 \mathrm{~L} / \mathrm{h}$ ) or spray-drying (feed rate $15 \mathrm{~mL} / \mathrm{min}$; inlet temperature $165^{\circ} \mathrm{C}$ ) [71]. In fact, casein arrangement of hydrophobic and hydrophilic amino acid residues makes it an ideal emulsifier [83]. SEDS-produced powder had an aw of 0.47 and spray-dried powder had an aw of 0.40 (at $26.6{ }^{\circ} \mathrm{C}$ ). Encapsulation efficiency was 92 and $79.3 \%$, respectively. The average diameter was 5.8 and 16.6 for SEDS-obtained powder and spray-dried powder, respectively. Both the SEDS and spray-drying techniques increased the storage stability of carotenoids with respect to the free oil. Examination of the inner structure of microcapsules produced by both SEDS and spray-drying methods provided some insight into the property differences: microcapsules produced with the SEDS had many fine pores that contained oil or $\mathrm{CO}_{2}$ gas, whereas those produced with the spray-drying method had heavy walls and large voids that contained oil and air [71]. The degradation rate for $\beta$-carotene was much lower than those found in previous studies cited above, with half-lives of 149 and $199 \mathrm{~d}$ for the spray-drying and SEDS techniques, respectively. This effect may be due to the combined presence of polysaccharides and protein in the wall material, that could provide a better protection then the separated polymers. Indeed, in a previous study on a system made with whey protein and pectin it was demonstrated that during heat drying, Maillard reaction occurs, leading to increased stability of the encapsulated $\beta$-carotene [71]. Moreover, the protection of $\beta$-carotene by tocopherols and tocotrienols cannot be ruled out.

Other combinations of polysaccharides with protein were investigated. Pullulan was used in combination with whey protein isolate to encapsulate $\beta$-carotene dissolved in medium-chain triacylglycerol oil by a pre-emulsification step followed by electrospraying (feed flow rate: $0.01 \mathrm{~mL} / \mathrm{min}$; voltage: $18 \mathrm{kV}$, temperature: $20^{\circ} \mathrm{C}$ ) [72]. In fact, in a previous study, pullulan alone displayed good film-forming properties but low emulsifying properties, resulting in low encapsulation efficiency [84]. Hence, whey proteins were used to improve the emulsifying properties [72]. The encapsulation efficiency was only $53 \%$. The average particle size of the powder was $0.54 \mu \mathrm{m}$. $\beta$-carotene degradation was modelled 
with Avrami's equation and was shown to follow diffusion limited model for aw 0.2 and first-order kinetic model for aw 0.4 and 0.6. From the equations provided, it could be calculated that the half-life of $\beta$-carotene was 46,81 and $86 \mathrm{~d}$ at room temperature and aw of $0.6,0.4$ and 0.2 , respectively. The lower stability of the nanocapsules at higher aw was attributed to pullulan dissolution [72].

In another approach, the emulsifier was functionalized to advance its performance. N-octenyl succinate anhydride (OSA)-modified starches, such as the commercial HI-CAP, CAPSUL and CAPSUL TA, have been developed to improve emulsifying and film-forming properties, low viscosities, high oil-loading capacities and oxygen barrier properties [85]. Hence, these compounds were applied with medium-chain triacylglycerol oil to form $\beta$-carotene $\mathrm{O} / \mathrm{W}$ nanoemulsions, with average particle size in the range $0.10-0.15 \mu \mathrm{m}$ depending on the modified starch used. These latter $\mathrm{O} / \mathrm{W}$ nanoemulsions were spraydried (air inlet temperature of $190{ }^{\circ} \mathrm{C}$, feed rate of $20 \mathrm{~mL} / \mathrm{min}$ ) but the encapsulation efficiency was not reported. $\beta$-carotene loss was studied during storage in the aw range 0.11-0.97 at $25^{\circ} \mathrm{C}$ for $30 \mathrm{~d}$. Differently from most of the other studies considered so far, which applied a first-order kinetics, $\beta$-carotene degradation was studied with the Weibull model. For the samples at aw $\leq 0.75$, the shape values were greater than 1 which indicates that the general shape of the degradation curve is convex with a fast degradation. When aw was 0.97 , the shape value was less than 1 or close to 1 , which indicated that the degradation curve is concave with the highest loss of $\beta$-carotene during the initial stage of storage [73]. Among the different modified starches, $\beta$-carotene degradation was minimum in HI-CAP and maximum in CAPSUL: this trend was associated to the oxygen permeability of the modified starches, which was lower for HI-CAP than for CAPSUL and CAPSUL TA [73]. In particular, $\beta$-carotene encapsulated in HI-CAP showed high stability in the glassy state, with a half-life of $53 \mathrm{~d}$ at aw 0.11 and $25^{\circ} \mathrm{C}$, which could be due to both the oxygen barrier properties of HI-CAP and to the smooth surface of the powder that was found to be more compact than the powders obtained with the other modified starches. In the powders obtained with CAPSUL and CAPSUL TA, the stability was very low, below an aw of 0.75 , but the degradation rate sharply decreased at aw 0.97 , where the material was collapsed [73], thus confirming previous findings [62].

Another strategy to increase $\beta$-carotene stability is to co-encapsulate an antioxidant compound. To this aim, $\beta$-carotene was dissolved in flaxseed oil with eugenol and mixed with two types of OSA starches differing for the molecular weight (MW $9.4 \times 10^{5}$ or MW $5.3 \times 10^{6}$ ), passed through a microfluidizer and the spray-dried (feed rate: $10 \mathrm{~mL} / \mathrm{min}$, inlet temperature: $170{ }^{\circ} \mathrm{C}$ ) [74]. The encapsulation efficiency was approximately $90 \%$ in both systems. The aw was below 0.26 and $\mathrm{Tg}$ was not reported, but the systems likely were in the glassy state. The particle size was found to be 0.126 and 0.241 , with the highest value found for the system with the highest MW OSA starch. Upon storage at $40{ }^{\circ} \mathrm{C}$, it was observed that eugenol was effective in protecting $\beta$-carotene from degradation, with the half-life increasing from $21 \mathrm{~d}$ in absence of eugenol to more than $30 \mathrm{~d}$ in presence of eugenol. The molecular weight of OSA starch was also important; in fact, lower MW starch provided better protection. This effect was attributed to tight adsorption of emulsifier at the interface, lower viscosity, reduced entrapment of air in emulsion feed for spray drying and finally formation of a stable film with high viscoelasticity that prevented the oxidation of core material [74].

In a following approach, multiple strategies were combined together to enhance protection of $\beta$-carotene. In fact, a high concentration of a hydrophilic solid compound, i.e., sucrose, was dissolved in the emulsion to be dried as proposed previously [69]. Moreover, antioxidants were added in both the hydrophilic phase and the lipid phase. To this aim, $\beta$-carotene and $\alpha$-tocopherol were dissolved in corn oil and then homogenized at high pressure with a solution containing OSA starch, ascorbic acid and various amounts of sucrose before spray-drying (inlet temperature at $170{ }^{\circ} \mathrm{C}$; air pressure of the atomizer $0.4 \mathrm{MPa}$, feed rate $500-1500 \mathrm{~mL} / \mathrm{h}$, inlet hot air rate $\left.50-300 \mathrm{~m}^{3} / \mathrm{h}\right)$. [75]. The surface oil was less than $5 \%$ and slightly decreased with increasing sucrose content. With an increasing 
ratio of sucrose, the average size of the emulsion droplets decreased. For instance, when the OSA: sucrose ratio was $1: 1$, the average size was $0.25 \mu \mathrm{m}$. The aw was 0.26 whatever the sucrose content, while the $\mathrm{Tg}$ of the wall material decreased with increasing sucrose content, even if in any case it was well above room temperature, indicating that the dried $\mathrm{O} / \mathrm{W}$ emulsions were in the glassy state. The dried emulsions were stored for $30 \mathrm{~d}$ at $60{ }^{\circ} \mathrm{C}$ and found to be very stable. For instance, when OSA: sucrose ratio was 1:1, the half-life for $\beta$-carotene degradation was higher than $30 \mathrm{~d}$ at $60^{\circ} \mathrm{C}$, suggesting that the dried emulsions would be very stable at room temperature [75].

\subsection{Activation Energy for $\beta$-Carotene Degradation}

Few studies have investigated the activation energy for $\beta$-carotene degradation (Table 2). In carrot, the activation energy for $\beta$-carotene degradation was found to depend slightly on the aw level, with values ranging from about 16 to about $18 \mathrm{~kJ} / \mathrm{mol}$ at aw of 0.10 and 0.30 , respectively [21]. From the kinetic data describing $\beta$-carotene degradation in room-temperature-dried molecular complexes made with amylose and ascorbyl palmitate, an activation energy of about $23 \mathrm{~kJ} / \mathrm{mol}$ was calculated using the Arrhenius equation [64]. In spray-dried emulsions or emulsions dried by $\mathrm{SC}-\mathrm{CO}_{2}$, made with palm oil-containing tocopherols and tocotrienols, maltodextrins DE 10, sodium caseinate and soy lecithin activation energy was found to be 25 and $29 \mathrm{~kJ} / \mathrm{mol}$, respectively [71]. Since these latter systems only differed for the microstructure, this result seems to indicate that the microstructure may slightly affect activation energy.

Spray-died systems made with sunflower oil, trehalose, whey protein and maltodextrins MD 23-27, with or without a second layer of Arabic gum, showed that the activation energy for $\beta$-carotene degradation was different in the temperature range below $\mathrm{Tg}$ and above Tg [70], suggesting that the viscosity of the matrix and its porosity also affects the activation energy, probably affecting heat transfer. Moreover, the freeze-dried systems obtained with the same ingredients (without maltodextrins) had higher activation energies that those of the spray-dried systems, which differed in the temperature range below $\mathrm{Tg}$ and above $\mathrm{Tg}$, confirming that the microstructure of the matrix affects heat transfer kinetics [69]. As a general conclusion, beside the role of the ingredients of the formulations, the impact of the microstructure on activation energy seem to be relevant and needs further investigation.

\section{Conclusions and Future Perspectives}

Considering a dried natural matrix such as carrot powder, little protection of $\beta$ carotene occurs during storage, with a half-life below $16 \mathrm{~d}$ at $25^{\circ} \mathrm{C}$ and minimal stability at low aw, where the system is in the glassy state. Despite the low molecular mobility of the glassy state, small molecules such as oxygen can diffuse in the matrix, promoting oxidation, probably due to the porous structure of the glassy system. The development of micro- and nano-structures for $\beta$-carotene stabilization is challenging. One strategy to increase the stability of $\beta$-carotene in the glassy state was to apply high concentrations of hydrophilic solids (trehalose or sucrose) in the mixture to be dried, which led to a low amount of occluded air in the powder. The use of antioxidant compounds having various polarities, such as ascorbic acid, eugenol and tocopherol, co-encapsulated in the microand nano-structures, was also successful to decrease the degradation rate of $\beta$-carotene. Moreover, a promising approach was to increase the performance of the interface between the air and oil phase in which $\beta$-carotene was dissolved, by using multilayer biopolymers, proteins linked to polysaccharides via the Maillard reaction or functionalized biopolymers such as OSA modified starches. By these approaches, the half-life of $\beta$-carotene could increase up to about $200 \mathrm{~d}$ at $25^{\circ} \mathrm{C}$.

Future research needs to extend data on the activation energy and the effect of aw on $\beta$-carotene degradation, in order to accurately predict the stability of the designed structures upon environmental temperature and humidity fluctuations. Moreover, advance knowledge on oxygen permeability across various interfaces, as affected by temperature, aw and Tg of the system, could lead to the selection of the most appropriate biopolymers 
for $\beta$-carotene protection and to better explore the potential of the wide array of natural biopolymers as barrier materials for $\beta$-carotene encapsulation.

Author Contributions: Conceptualization, V.L. and J.S.; methodology, V.L.; investigation, data curation, writing, review and editing, V.L. and J.S.; supervision, V.L. All authors have read and agreed to the published version of the manuscript.

Funding: This research received no external funding.

Conflicts of Interest: The authors declare no conflict of interest.

\section{References}

1. Awasthi, S.; Awasthi, A. Role of vitamin A in child health and nutrition. Clin. Epidemiol. Glob. Health 2020, 8, 1039-1042. [CrossRef]

2. Stephensen, C.B.; Lietz, G. Vitamin A in resistance to and recovery from infection: Relevance to SARS-CoV2. Br. J. Nutr. 2021, 126, 1663-1672. [CrossRef] [PubMed]

3. Afolami, I.; Samuel, F.; Borgonjen-van den Berg, K.; Mwangi, M.N.; Kalejaiye, O.; Sanusi, R.A.; Putri, L.A.R.; Brivio, F.; Brouwer, I.D.; Melse-Boonstra, A. The contribution of provitamin A biofortified cassava to vitamin A intake in Nigerian preschoolchildren. Br. J. Nutr. 2021, 126, 1364-1372. [CrossRef] [PubMed]

4. Melendez-Martinez, A.J. An overview of carotenoids, apocarotenoids and vitamin A in agro-food, nutrition, health and disease. Mol. Nutr. Food Res. 2019, 63, 1801045. [CrossRef]

5. Kawata, A.; Murakami, Y.; Suzuki, S.; Fujisawa, S. Anti-inflammatory activity of $\beta$-carotene, lycopene and tri- $n$-butylborane, a scavenger of reactive oxygen species. In Vivo 2018, 32, 255-264. [CrossRef]

6. Boccardi, V.; Arosio, B.; Cari, L.; Bastiani, P.; Scamosci, M.; Casati, M.; Ferri, E.; Bertagnoli, L.; Ciccone, S.; Rossi, P.D.; et al. Beta-carotene, telomerase activity and Alzheimer's disease in old age. Eur. J. Nutr. 2020, 59, 119-126. [CrossRef]

7. Yusuf, I.F.; Lesmana, R.; Goenawan, H.; Achadiyani, A.; Khairani, A.F.; Fatimamah, S.N. The roles of $\beta$-carotene in cardiomyocytes. Curr. Nutr. Food Sci. 2021, 17, 673-678. [CrossRef]

8. Sluijs, I.; Cadier, E.; Beulens, J.W.J.; Spijkerman, A.M.W.; van der Schow, Y.T. Dietary intake of carotenoids and risk of type 2 diabetes. Nutr. Metab. Cardiovasc. Dis. 2015, 25, 376-381. [CrossRef]

9. Di Carlo, E.; Augustin, A.J. Prevention of the onset of age-related macular degeneration. J. Clin. Med. 2021, 10, 3297. [CrossRef]

10. Chen, Q.-H.; Wu, B.-K.; Pan, D.; Sang, L.-X.; Chang, B. Beta-Carotene and its protective effect on gastric cancer. World J. Clin. Cases 2021, 9, 6591-6607. [CrossRef]

11. Meléndez-Martínez, A.J.; Böhm, V.; Borge, G.I.A.; Cano, M.P.; Fikselová, M.; Gruskiene, R.; Lavelli, V.; Loizzo, M.R.; Mandić, A.I.; Mapelli-Brahm, P.; et al. Carotenoids: Considerations for their use in functional foods, nutraceuticals, nutricosmetics, supplements, botanicals, and novel foods in the context of sustainability, circular economy, and climate change. Ann. Rev. Food Sci. Tech. 2021, 12, 14.1-14.28. [CrossRef] [PubMed]

12. Springmann, M.; Wiebe, K.; Mason-D'Croz, D.; Sulser, T.B.; Rayner, M.; Scarborough, P. Health and nutritional aspects of sustainable diet strategies and their association with environmental impacts: A global modelling analysis with country-level detail. Lancet Planet. Health 2018, 2, 451-461. [CrossRef]

13. Bohn, T.; McDougall, G.J.; Alegría, A.; Alminger, M.; Arrigoni, E.; Aura, A.-M.; Brito, C.; Cilla, A.; El, S.N.; Karakaya, S.; et al. Mind the gap-deficits in our knowledge of aspects impacting the bioavailability of phytochemicals and their metabolites: A position paper focusing on carotenoids and polyphenols. Mol. Nutr. Food Res. 2015, 59, 1307-1323. [CrossRef]

14. Rodriguez-Concepcion, M.; Avalos, J.; Bonet, M.L.; Boronat, A.; Gomez-Gomez, L.; Hornero-Mendez, D.; Limon, M.C.; Meléndez-Martínez, A.J.; Olmedilla-Alonso, B.; Palou, A.; et al. A global perspective on carotenoids: Metabolism, biotechnology, and benefits for nutrition and health. Prog. Lipid Res. 2018, 70, 62-93. [CrossRef] [PubMed]

15. Boon, C.S.; McClements, D.J.; Weiss, J.; Decker, E.A. Factors influencing the chemical stability of carotenoids in foods. Crit. Rev. Food Sci. Nutr. 2010, 50, 515-532. [CrossRef] [PubMed]

16. Knockaert, G.; Pulissery, S.K.; Lemmens, L.; Buggenhout, S.V.; Hendrickx, M.; Loey, A.V. Carrot beta-carotene degradation and isomerization kinetics during thermal processing in the presence of oil. J. Agric. Food Chem. 2012, 60, 10312-10319. [CrossRef]

17. Colle, I.J.P.; Lemmens, L.; Knockaert, G.; Loey, V.A.; Henderickx, M. Carotene degradation and isomerization during thermal processing: A review on kinetic aspects. Crit. Rev. Food Sci. Nutr. 2016, 56, 1844-1855. [CrossRef]

18. Martin, D.; Amado, A.M.; Gonzálvez, A.G.; Marques, M.P.M.; Batista de Carvalho, L.A.E.; Ureña, A.G. FTIR Spectroscopy and DFT calculations to probe the kinetics of $\beta$-carotene thermal degradation. J. Phys. Chem. A 2019, 123, 5266-5273. [CrossRef]

19. Mordi, R.C. Mechanism of $\beta$-carotene degradation. Biochem. J. 1993, 292, 310-312. [CrossRef]

20. Sarpong, F.; Zhou, C.; Bai, J.; Amenorfe, L.P.; Golly, M.K.; Ma, H. Modeling of drying and ameliorative effects of relative humidity (RH) against $\beta$-carotene degradation and color of carrot (Daucus carota var.) slices. Food Sci. Biotechnol. 2019, 28, 75-85. [CrossRef]

21. Meléndez-Martínez, A.J.; Mandić, A.I.; Bantis, F.; Böhm, V.; Borge, G.I.A.; Brnčić, M.; Bysted, A.; Cano, M.P.; Dias, M.G.; Elgersma, A.; et al. A comprehensive review on carotenoids in foods and feeds: Status quo, applications, patents and research needs. Crit. Rev. Food Sci. Nutr. 2021, 1-51. [CrossRef] [PubMed]

22. Lavelli, V. Circular food supply chains-Impact on value addition and safety. Trends Food Sci. Technol. 2021, 114, 323-332. [CrossRef] 
23. Tan, Y.; McClements, D.J. Improving the bioavailability of oil-soluble vitamins by optimizing food matrix effects: A review. Food Chem. 2021, 348, 129148. [CrossRef] [PubMed]

24. Lavelli, V.; Sereikaite, J. Kinetic study of encapsulated $\beta$-carotene degradation in aqueous environments: A review. Foods 2022, 11,317. [CrossRef]

25. Bradford, K.J.; Dahala, P.; van Asbrouck, J.; Kunusothc, K.; Bello, P.; Thompsond, J.; Wue, F. The dry chain: Reducing postharvest losses and improving food safety in humid climates. Trends Food Sci. Technol. 2018, 71, 84-93. [CrossRef]

26. Sanjuan, N.; Stoessel, F.; Hellweg, S. Closing data gaps for LCA of food products: Estimating the energy demand of food processing. Environ. Sci. Technol. 2014, 48, 1132-1140. [CrossRef]

27. Cullen, P.J.; Tiwari, B.K.; O'Donnell, C.P.; Muthukumarappan, K. Modelling approaches to ozone processing of liquid foods. Trends Food Sci. Technol. 2009, 20, 125-136. [CrossRef]

28. López-Gámez, G.; Elez-Martínez, P.; Martín-Belloso, O.; Soliva-Fortuny, R. Applying pulsed electric fields to whole carrots enhances the bioaccessibility of carotenoid and phenolic compounds in derived products. Foods 2021, 10, 1321. [CrossRef]

29. Elik, A.; Yanik, D.K.; Gogüş, F. Microwave-assisted extraction of carotenoids from carrot juice processing waste using flaxseed oil as a solvent. LWT-Food Sci. Technol. 2020, 123, 109100. [CrossRef]

30. Chuyen, H.V.; Nguyen, M.H.; Roach, P.D.; Golding, J.B.; Parks, S.E. Microwave-assisted extraction and ultrasound-assisted extraction for recovering carotenoids from Gac peel and their effects on antioxidant capacity of the extracts. Food Sci. Nutr. 2018, 6, 189-196. [CrossRef]

31. Civan, M.; Kumcuoglu, S. Green ultrasound-assisted extraction of carotenoid and capsaicinoid from the pulp of hot pepper paste based on the bio-refinery concept. LWT-Food Sci. Technol. 2019, 113, 108320. [CrossRef]

32. Patel, A.S.; Kar, A.; Dash, S.; Dash, S.K. Supercritical fluid extraction of $\beta$-carotene from ripe bitter melon pericarp. Sci. Rep. 2019, 9, 1-10. [CrossRef]

33. Del Pilar Sanchez-Camargo, A.; Gutierrez, L.-F.; Vargas, S.M.; Martinez-Correa, H.A.; Parada-Alfonso, F.; Narvaez-Cuenca, C.-E. Valorisation of mango peel: Proximate composition, supercritical fluid extraction of carotenoids, and application as an antioxidant additive for an edible oil. J. Supercrit. Fluids 2019, 152, 104574. [CrossRef]

34. Mustafa, A.; Trevino, L.M.; Turner, C. Pressurized hot ethanol extraction of carotenoids from carrot by-products. Molecules 2012, 17, 1809-1818. [CrossRef] [PubMed]

35. Lara-Abia, S.; Gomez-Maqueo, A.; Welti-Chanes, J.; Cano, M.P. High hydrostatic pressure-assisted extraction of carotenoids from papaya (Carica papaya L. cv. Maradol) tissues using soybean and sunflower oil as potential green solvents. Food Eng. Rev. 2021, 13, 660-675. [CrossRef]

36. Jayesree, N.; Hang, P.K.; Priyangaa, A.; Krishnamurthy, N.P.; Ramanan, R.N.; Turki, M.S.A.; Galanakis, M.C.; Ooi, C.W. Valorisation of carrot peel waste by water-induced hydrocolloidal complexation for extraction of carrot and pectin. Chemosphere 2021, 272, 129919. [CrossRef]

37. De Freitas Santos, P.D.; Rubio, F.T.V.; da Silva, M.P.; Pinho, L.S.; Favaro-Trindade, C.S. Microencapsulation of carotenoid-rich materials: A review. Food Res. Int. 2021, 147, 110571. [CrossRef]

38. Rostamabadi, H.; Falsafi, S.R.; Jafari, S.M. Nanoencapsulation of carotenoids within lipid-based nanocarriers. J. Control. Release 2019, 298, 38-67. [CrossRef]

39. Ratti, C. Freeze drying for food powder production. In Handbook of Food Powders: Process and Properties; Woodhead Publishing: Cambridge, UK, 2013; pp. 57-84.

40. Bhatta, S.; Stevanovic, T.; Ratti, C. Freeze-Drying of plant-based foods. Foods 2020, 9, 87. [CrossRef]

41. Harnkarnsujarit, N.; Charoenrein, S.; Roos, Y.H. Microstructure formation of maltodextrin and sugar matrices in freeze-dried systems. Carbohydr. Polym. 2012, 88, 734-742. [CrossRef]

42. Munoz-Ibanez, M.; Nuzzo, M.; Turchiuli, C.; Bergenståhl, B.; Dumoulin, E.; Millqvist-Fureby, A. The micro-structure and component distribution in spray-dried emulsion particles. Food Struct. 2016, 8, 16-24. [CrossRef]

43. Shishir, M.R.I.; Chen, W. Trends of spray drying: A critical review on drying of fruit and vegetable juices. Trends Food Sci. Technol. 2017, 65, 49-67. [CrossRef]

44. Barbosa-Canovas, G.V.; Juliano, P. Physical and chemical properties of food powders. In Encapsulated and Powdered Foods; Onwulata, C., Ed.; CRC Press: Washington, DC, USA; Taylor \& Francis Group: Abingdon, UK, 2005; pp. 39-71.

45. Kankala, R.K.; Chen, B.-Q.; Liu, C.-G.; Tang, H.-X.; Wang, S.-B.; Chen, A.-Z. Solution-enhanced dispersion by supercritical fluids: An ecofriendly nanonization approach for processing biomaterials and pharmaceutical compounds. Int. J. Nanomed. 2018, 13, 4227-4245. [CrossRef] [PubMed]

46. Tabasinejad, F.; Moore, R.G.; Mehta, S.A.; van Fraassen, K.C.; Barzin, Y. Water solubility in supercritical methane, nitrogen, and carbon dioxide: Measurement and modeling from 422 to $483 \mathrm{~K}$ and pressures from 3.6 to $134 \mathrm{MPa}$. Ind. Eng. Chem. Res. 2011, 50, 4029-4041. [CrossRef]

47. Rodrigues, M.A.; Li, J.; Almeida, A.J.; Matos, H.A.; Gomes de Azevedo, E. Efficiency of water removal from water/ethanol mixtures using supercritical carbon dioxide. Braz. J. Chem. Eng. 2006, 23, 205-212. [CrossRef]

48. Bock, N.; Dargaville, T.R.; Woodruff, M.A. Electrospraying of polymers with therapeutic molecules: State of the art. Prog. Polym. Sci. 2012, 37, 1510-1551. [CrossRef]

49. Bhushani, J.A.; Anandharamakrishnan, C. Electrospinning and electrospraying techniques: Potential food based applications. Trends Food Sci. Technol. 2014, 38, 21-33. [CrossRef] 
50. Chirife, J.; Buera, M.D.P. Water activity, water glass dynamics, and the control of microbiological growth in foods. Crit. Rev. Food Sci. Nutr. 1996, 36, 465-513. [CrossRef]

51. Olaimat, A.N.; Osaili, T.M.; Al-Holy, M.A.; Al-Nabulsi, A.A.; Obaid, R.S.; Alaboudi, A.R.; Ayyash, M.; Holley, R. Microbial safety of oily, low water activity food products: A review. Food Microbiol. 2020, 92, 103571. [CrossRef]

52. Rahman, S. Water activity and sorption properties of food. In Food Properties Handbook; Clydesdale, F.M., Ed.; CRC Press: Boca Raton, FL, USA, 1995; pp. 1-83.

53. Andersen, A.B.; Risbo, J.; Andersen, M.L.; Skibsted, L.H. Oxygen permeation through an oil-encapsulating glassy food matrix studied by ESR line broadening using a nitroxyl spin probe. Food Chem. 2000, 70, 499-508. [CrossRef]

54. Hung, L.; Horagai, Y.; Kimura, Y.; Adachi, S. Decomposition and discoloration of L-ascorbic acid freeze-dried with saccharides. Innov. Food Sci. Emerg. Technol. 2007, 8, 500-506. [CrossRef]

55. Lavelli, V.; Sri Harsha, P.S.C.; Laureati, M.; Pagliarini, E. Degradation kinetics of encapsulated grape skin phenolics and micronized grape skins in various water activity environments and criteria to develop wide-ranging and tailor-made food applications. Inn. Food Sci. Emerg. Technol. 2017, 39, 156-164. [CrossRef]

56. Le Meste, M.; Champion, D.; Roudaut, G.; Blond, G.; Simatos, D. Glass transition and food technology: A critical appraisal. J. Food Sci. 2002, 67, 2444-2458. [CrossRef]

57. Roos, Y.H. Glass transition temperature and its relevance in food processing. Ann. Rev. Food Sci. Technol. 2010, 1, 469-496. [CrossRef]

58. Labuza, T.P.; McNally, L.; Gallagher, D.; Hawkes, J. Stability of intermediate moisture foods. I. Lipid oxidation. J. Food Sci. 1972, 37, 154-159. [CrossRef]

59. Arya, S.S.; Natesan, V.; Parihar, D.B.; Vijayaraghavan, P.K. Stability of carotenoids in dehydrated carrots. J. Food Technol. 1979, 14, 579-586. [CrossRef]

60. Lavelli, V.; Zanoni, B.; Zaniboni, A. Effect of water activity on carotenoid degradation in dehydrated carrots. Food Chem. 2007, 104, 1705-1711. [CrossRef]

61. Iaccheri, E.; Castagnini, J.M.; Dalla Rosa, M.; Rocculi, P. New insights into the glass transition of dried fruits and vegetables and the effect of pulsed electric field treatment. Inn. Food Sci. Emerg. Technol. 2021, 67, 102566. [CrossRef]

62. Prado, S.M.; Buera, M.P.; Elizalde, B.E. Structural collapse prevents $\beta$-carotene loss in a supercooled polymer matrix. J. Agric. Food Chem. 2006, 54, 79-85. [CrossRef]

63. Yazdani, M.; Tavakoli, O.; Khoob, M.; Wu, Y.S.; Faramarzi, M.A.; Gholibegloo, E.; Farkhondeh, S. Beta-carotene/cyclodextrinbased inclusion complex: Improved loading, solubility, stability, and cytotoxicity. J. Incl. Phenom. Macrocycl. Chem. 2021, 102, 55-64. [CrossRef]

64. Kong, L.; Bhosale, R.; Ziegler, G.R. Encapsulation and stabilization of $\beta$-carotene by amylose inclusion complexes. Food Res. Int 2018, 105, 446-452. [CrossRef] [PubMed]

65. Harnkarnsujarit, N.; Charoenrein, S.; Roos, Y.H. Reversed phase HPLC analysis of stability and microstructural effects on degradation kinetics of $\beta$-carotene encapsulated in freeze-dried maltodextrin-emulsion systems. J. Agric. Food Chem. 2012, 60, 9711-9718. [CrossRef] [PubMed]

66. Mahfoudhi, N.; Hamdi, S. Kinetic degradation and storage stability of $\beta$-carotene encapsulated by freeze-drying using almond gum and gum Arabic as wall materials. J. Food Process. Preserv. 2014, 39, 896-906. [CrossRef]

67. Mahfoudhi, N.; Hamdi, S. Kinetic degradation and storage stability of $\beta$-carotene encapsulated by spray drying using almond gum and gum Arabic as wall materials. J. Polym. Eng. 2014, 34, 683-693. [CrossRef]

68. Rodriguez-Huezo, M.E.; Pedroza-Islas, R.; Prado-Barragan, L.A.; Beristain, C.I.; Vernon-Cartier, E.J. Microencapsulation by spray drying of multiple emulsions containing carotenoids. J. Food Sci. 2004, 69, E351-E359. [CrossRef]

69. Lim, A.S.L.; Griffin, C.; Roos, Y.R. Stability and loss kinetics of lutein and $\beta$-carotene encapsulated in freeze-dried emulsions with layered interface and trehalose as glass former. Food Res. Int. 2014, 62, 403-409. [CrossRef]

70. Lim, A.S.L.; Roos, Y.H. Spray drying of high hydrophilic solids emulsions with layered interface and trehalose-maltodextrin as glass formers for carotenoids stabilization. J. Food Eng. 2016, 171, 174-184. [CrossRef]

71. Lee, W.J.; Tan, C.P.; Sulaiman, R.; Smith, R.L.; Chong, G.H. Microencapsulation of red palm oil as an oil-in-water emulsion with supercritical carbon dioxide solution-enhanced dispersion. J. Food Eng. 2018, 222, 100-109. [CrossRef]

72. Niu, B.; Shao, P.; Feng, S.; Qiu, D.; Sun, P. Rheological aspects in fabricating pullulan-whey protein isolate emulsion suitable for electrospraying: Application in improving $\beta$-carotene stability. LWT-Food Sci. Technol. 2020, 129, 109581. [CrossRef]

73. Liang, R.; Huang, Q.; Maa, J.; Shoemaker, C.F.; Zhong, F. Effect of relative humidity on the store stability of spray-dried betacarotene nanoemulsions. Food Hydrocoll. 2013, 33, 225-233. [CrossRef]

74. Sharif, H.R.; Goff, H.D.; Majeed, H.; Shamoon, M.; Liu, F.; Nsor-Atindana, J.; Haider, J.; Liang, R.; Zhong, F. Physicochemical properties of $\beta$-carotene and eugenol coencapsulated flax seed oil powders using OSA starches as wall material. Food Hydrocoll. 2017, 73, 274-283. [CrossRef]

75. Chen, X.; Liang, R.; Zhong, F.; Ma, J.; John, N.-A.; Goff, H.D.; Yokoyama, W.H. Effect of high concentrated sucrose on the stability of OSA-starch-based beta-carotene microcapsules. Food Hydrocoll. 2021, 113, 105472. [CrossRef]

76. De Oliveira, V.E.; Almeida, E.W.; Castro, H.V.; Edwards, H.G.; Dos Santos, H.F.; de Oliveira, L.F.C. Carotenoids and $\beta$-cyclodextrin inclusion complexes: Raman spectroscopy and theoretical investigation. J. Phys. Chem. A 2011, 115, 8511-8519. [CrossRef] 
77. Ozturk, B. Nanoemulsions for food fortification with lipophilic vitamins: Production challenges, stability, and bioavailability. Eur. J. Lipid Sci. Technol. 2017, 119, 1500539. [CrossRef]

78. Avaltroni, F.; Bouquerand, P.E.; Normand, V. Maltodextrin molecular weight distribution influence on the glass transition temperature and viscosity in aqueous solutions. Carbohydr. Polym. 2004, 58, 323-334. [CrossRef]

79. Dickinson, E. Hydrocolloids at interfaces and the influence on the properties of the dispersed systems. Food Hydrocoll. 2003, 17, 25-39. [CrossRef]

80. Mahfoudhi, N.; Chouaibi, M.; Donsì, F.; Ferrari, G.; Hamdi, S. Chemical composition and functional properties of gum exudates from the trunk of the almond tree (Prunus dulcis). Food Sci. Technol. Int. 2012, 18, 241-250. [CrossRef]

81. Mahfoudhi, N.; Sessa, M.; Chouaibi, M.; Ferrari, G.; Donsì, F.; Hamdi, S. Assessment of emulsifying ability of almond gum in comparison with gum arabic using response surface methodology. Food Hydrocoll. 2014, 37, 49-59. [CrossRef]

82. Muschiolik, G.; Dickinson, E. Double emulsions relevant to food systems: Preparation, stability, and applications. Compr. Rev. Food Sci. Food Saf. 2017, 16, 532-555. [CrossRef]

83. Farshchi, A.; Ettelaie, R.; Holmes, M. Influence of $\mathrm{pH}$ value and locust bean gum concentration on the stability of sodium caseinate-stabilized emulsions. Food Hydrocoll. 2013, 32, 402-411. [CrossRef]

84. Shao, P.; Niu, B.; Chen, H.; Sun, P. Fabrication and characterization of tea polyphenols loaded pullulan-CMC electrospun nanofiber for fruit preservation. Int. J. Biol. Macromol. 2018, 107, 1908-1914. [CrossRef] [PubMed]

85. Sweedman, M.C.; Tizzotti, M.J.; Schäfer, C.; Gilbert, R.G. Structure and physicochemical properties of octenyl succinic anhydride modified starches: A review. Carbohydr. Polym. 2013, 92, 905-920. [CrossRef] [PubMed] 